\title{
25. AGE OF A BASALT INTRUSION ESTIMATED BY ORGANIC GEOCHEMISTRY
}

\author{
Douglas W. Waples, Department of Chemistry and Geochemistry, Colorado School of Mines, Golden, Colorado
}

\section{INTRODUCTION}

Many workers have noted that organic material close to igneous intrusions shows signs of increased thermal stress. In general, thermal effects are confined to the immediate vicinity of intrusions, extending into clastic sedimentary rocks a distance not more than twice the thickness of the dike or sill (Bostick, 1974; Correia and Maury, 1975; Kendrick et al., 1977). Dutcher et al. (1966), however, detected thermal metamorphism in coal seams at a distance of 5 feet from a 1-foot-thick igneous sill. Differences in the effects of igneous intrusions on coal seams and on dispersed kerogen in shales may be due to differences in thermal conductivities and to the varying importance of convective heat transfer through superheated water in sediments of different permeability. Few data have been compiled on igneous intrusives in unconsolidated sediments and how their effects compare with intrusions into lithified sediments (Baker, et al., 1977).

Kerogen exposed to the high temperatures of igneous intrusions exhibits the same general characteristics as kerogen which has followed normal geological maturation at lower temperatures for much longer time periods (Bostick, 1974). Vitrinite reflectance, for example, is increased (Dutcher et al., 1966; Baker et al., 1977), and atomic H/C ratios are decreased (Dutcher et al., 1966). In the few studies made of such samples, EPR spectra and pyrolysis data (Baker et al., 1977) also indicate increased degrees of thermal metamorphism.

Several of the holes drilled on Deep Sea Drilling Project Leg 58 penetrated alternating layers of basalt and sediment. Recovery of the interbedded sediments was often poor, and only a few actual sediment/basalt contacts were found. Shipboard analysis of the basalts often failed to indicate definitively whether they are sills or flows. At Site 444, organic geochemistry was used to estimate the time of emplacement of an interlayered basasit.

\section{RESULTS AND INTERPRETATION}

Organic-geochemistry data from Site 444 were used to estimate the age of the basalt layer. As Waples and Sloan (this volume) noted, a gradual decrease in organic carbon and nitrogen occurs with increasing sediment depth at the Leg 58 sites. Organic-carbon contents are plotted against burial depth and age in Figure 1 for Site 444 sediments.

Three features of the curve are immediately apparent. There is a decrease in organic-carbon content

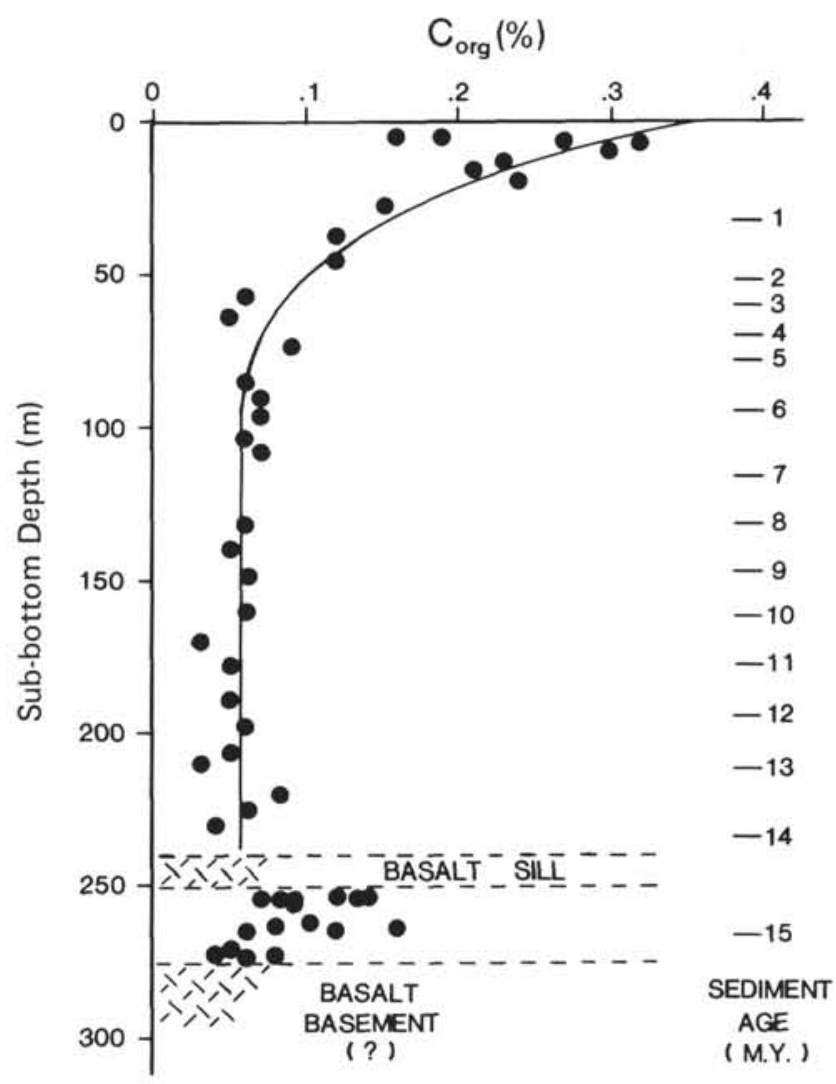

Figure 1. Organic-carbon content as a function of depth, Site 444 sediments.

from the sediment/water interface to a depth of about 90 meters, below which organic carbon remains constant at about 0.06 per cent. Second, organic-carbon contents in the first 10 meters below the basalt layer are significantly higher than in the 150 meters immediately above it. Finally, the organic-carbon contents of sediments more than 10 meters below the basalt layer are similar to those in the sediments overlying it.

The second and third points are emphasized in Figure 2 , in which organic-carbon contents for three different sections of the profile are shown in histogram form. It is clear that the populations of organic-carbon contents above and immediately below the basalt layer are different. Although data for samples more than 12 meters (one sill thickness) below the basalt are sparse, the samples seem to be similar in organic-carbon content to those overlying the basalt.

It appears from Figures 1 and 2, therefore, that the sediments beneath the basalt layer which were within the 


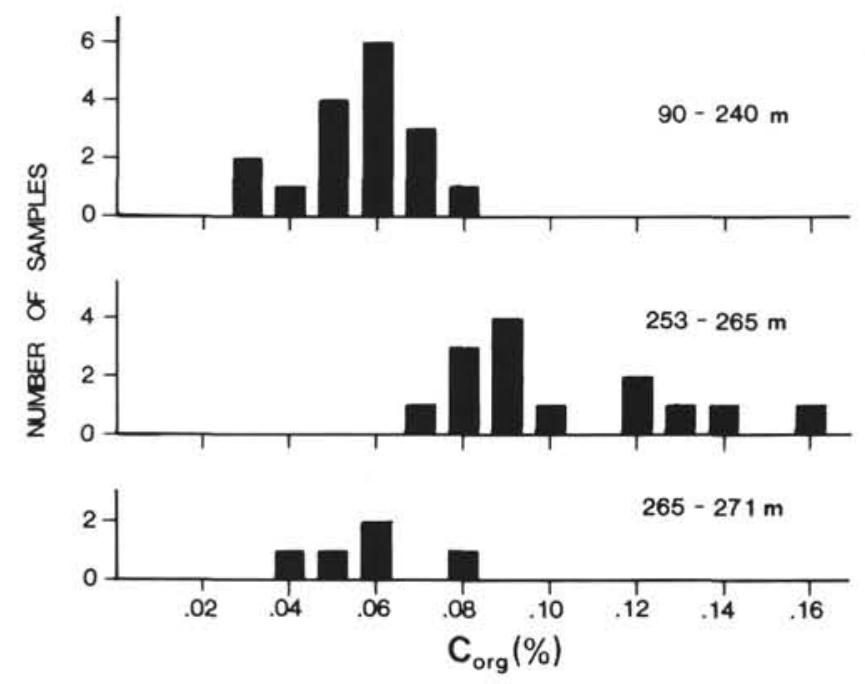

Figure 2. Organic-carbon contents for different portions of the section: 90-240 meters sub-bottom, sediments overlying basalt layer; 253-265 meters, sediments less than one layer thickness below layer; $265-$ 271 meters, sediments more than one layer thickness below layer.

zone heated by the igneous activity have anomalously high organic-carbon contents. Since there was no apparent difference in depositional environment through the section, these organic-carbon anomalies must be related to the emplacement of the basalt.

Furthermore, if the basalt were intrusive, the sediments less than 10 meters above it should also show elevated organic-carbon contents. Unfortunately, recovery of sediments in the 10 meters overlying the basalt was very poor, and no samples were available for analysis by organic geochemistry.

A possible explanation for the anomalously high organic-carbon contents in the sediments pyrolyzed by the basalt is that bacterial degradation of the organic matter did not occur because the pyrolyzed carbon could not be consumed by bacteria. Waples and Sloan (this volume) have proposed that in these pelagic and hemipelagic sediments bacterial diagenesis acting over as much as hundreds of meters of sediment depth and over periods of as much as $5 \mathrm{~m}$.y. is responsible for the gradual depletion of organic carbon. Furthermore, any bacterial diagenesis should be very sensitive to the nature of the organic material. Organic carbon deficient in nutritional value will not support a bacterial ecosystem, and therefore will not be degraded. This is precisely what is observed between 90 and 240 meters subbottom depth at Site 444 , where bacterial degradation has in fact ceased because the microbes have exhausted the nutrients.

Pyrolysis of organic carbon by nearby igneous activity would also terminate bacterial diagenesis. Pyrolysis would kill any microbes present, but this effect would be only temporary, since recolonization should occur rapidly if the necessary nutrients are present. However, pyrolysis has also destroyed the biodegradable organic carbon utilized by the bacteria, effectively preventing any further bacterial diagenesis in the pyrolyzed sediments. Organic-carbon contents of the pyrolyzed sediments are thus higher than in the unpyrolyzed but bacterially degraded sediments, but are lower than they were in the sediment before pyrolysis, because of loss of $\mathrm{CO}_{2}, \mathrm{CH}_{4}$, etc, during pyrolysis. It is estimated that as much as 50 per cent of the organic carbon in a sediment will be lost as a result of pyrolysis near an igneous intrusion (Elmar Schiener, pers. comm.). Thus, the organiccarbon contents of the sediments underlying the basalt layer probably represent between 50 and 100 per cent of the organic-carbon content at the time of basalt emplacement.

Organio-carbon contents of these sediments thus can be used to determine the time of emplacement and whether the basalt is intrusive or extrusive. Once the normal curve of organic-carbon depletion for the section has been determined (Figure 1), the average organic-carbon content for the pyrolyzed sediments calculated, and an appropriate correction made for possible loss of organic carbon during pyrolysis, the age of the sediments at the time of basalt emplacement can be determined merely by fitting the corrected organiccarbon content to the depletion curves.

For the present case, the following calculations are made:

$$
\begin{aligned}
& \text { Average } \mathrm{C}_{\text {org }} \text { of pyrolyzed sediments }=0.095 \\
& \text { Range of } \mathrm{C}_{\text {org }} \text { corrected for as much as } 50 \% \text { loss of } \\
& \mathrm{C} \text { during pyrolysis }=0.095 \text { to } 0.19
\end{aligned}
$$

This range of $\mathrm{C}_{\text {org }}$ values is then located on the normal depletion curve, as shown in Figure 3, and the ages corresponding to that organic-carbon content are bracketed. Thus, the basalt was emplaced when the underlying sediments were from 0.7 to $2.0 \mathrm{~m}$.y. old. Since micropaleontological studies indicate that those sediments were deposited about $14.2 \mathrm{Ma}$, the igneous event must have occurred between 12.2 and $13.5 \mathrm{Ma}$. A corollary of this conclusion is that the basalt must have been intrusive, since the basalt is significantly younger than the sediments which immediately overlie it.

McKee and Klock (this volume) report an age of $14.7 \pm 2.1 \mathrm{~m} . \mathrm{y}$. for the basalt intrusive; this age is based on $\mathrm{K}$ ô.r.dating of a whole-rock sample. Their data suggest that part of my estimated age range is too low, and that $12.6 \mathrm{~m}$.y. is the minimum age for the basalt. Otherwise, the radioisotope and organic-geochemistry data are compatible.

\section{CONCLUSIONS}

When an igneous sill or dike intrudes sediments in which organic diagenesis is not yet complete, pyrolysis of sedimented organic material may bring about premature cessation of bacterial degradation of organic material. At Site 444, this pyrolysis has resulted in the preservation of anomalously high concentrations of organic carbon in the pyrolyzed sediments 


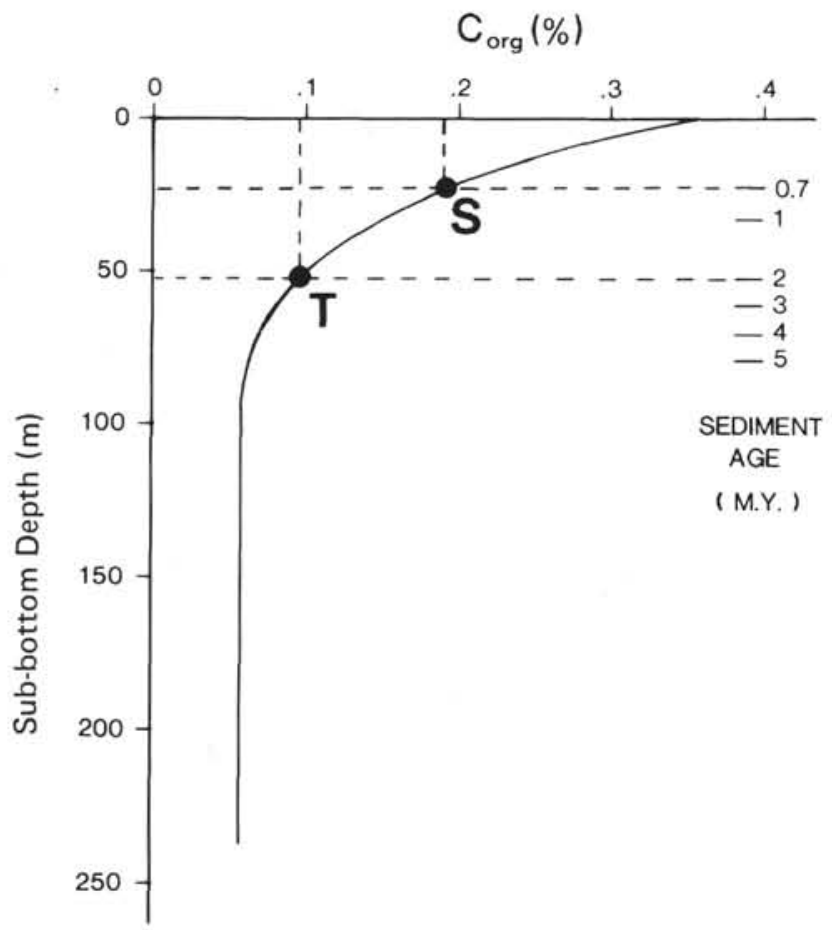

Figure 3. Dating the basalt layer. The range of corrected average contents of organic carbon in the pyrolyzed sediments $(0.095-0.19 \%)$ is plotted on the normal carbon-depletion curve as points $S$ and $T$. The upper and lower depth and age limits of the sediment at the time of basalt emplacement thus can be found graphically, as indicated.

Comparison of the anomalous organic-carbon contents with the curve of normal organic-carbon depletion for unpyrolyzed Site 444 sediments allowed estimation of the age of the basalt. If this approach is correct, then it can also be concluded that the basalt was intruded into unconsolidated sediments, rather than extruded at the sediment/water interface.

\section{ACKNOWLEDGMENT}

I thank Jean Whelan and George Claypool for helpful comments in reviewing the manuscript, and my shipboard colleagues for many stimulating discussions.

\section{REFERENCES}

Baker, E. W., Huang, W. Y., Rankin, J. G., Castaño, J. R., and Fuex, A. N., 1977. Electron paramagnetic resonance study of thermal alteration of kerogen in deep-sea sediments by basaltic sill intrusion. In Lancelot, Y., Siebold, E., et al., Init. Repts. DSDP, 41: Washington (U.S. Govt. Printing Office), pp. 839-847.

Bostick, N. H., 1974. Phytoclasts as indicators of thermal metamorphism, Franciscan Assemblage and Great Valley Sequence (Upper Mesozoic), California. Geological Society of America Special Paper, 153.

Correia, M. J., and Maury, R. C., 1975. Thermal, mineralogical, and chemical effects of the intrusion of a basaltic dike in the Toarcian of the causses. Bull. Centre Rech. Pau-SNPA, 9, 245-259.

Dutcher, R. R., Campbell, D. L., and Thornton, C. P., 1966. Coal metamorphism and igneous intrusives in Colorado. In Given, P. H. (Ed.), Coal Science: Washington (American Chemical Society), pp. 708-723.

Kendrick, J. W., Hood, A., and Castaño, J. R., 1977. Petroleum-generating potential of sediments from Leg 41, Deep Sea Drilling Project. In Lancelot, Y., Siebold, E., et al., Init. Repts. DSDP, 41: Washington (U. S. Govt. Printing Office), pp. 817-819. 